\title{
Microencapsulation of Probiotic Strains by Lyophilization Is Efficient in Maintaining the Viability of Microorganisms and Modulation of Fecal Microbiota in Cats
}

\author{
Bruna M. Rodrigues $\mathbb{D}^{1},{ }^{1}$ Paula M. Olivo, ${ }^{1}$ Milene P. Osmari, ${ }^{1,2}$ Ricardo S. Vasconcellos, \\ Leonir B. Ribeiro ${ }^{D}{ }^{1}{ }^{1}$ Ferenc I. Bankuti, ${ }^{1}$ and Magali S. S. Pozza ${ }^{1}$ \\ ${ }^{1}$ Animal Science Department, State University of Maringá, Avenida Colombo, 5790, Maringá, Paraná 87020-900, Brazil \\ ${ }^{2}$ Federal University of Santa Catarina, Engenheiro Agronômico Andrei Cristian Ferreira St., Florianópolis, \\ Santa Catarina, Brazil
}

Correspondence should be addressed to Bruna M. Rodrigues; bmrodrigues@live.com

Received 16 December 2019; Revised 23 June 2020; Accepted 10 July 2020; Published 30 July 2020

Academic Editor: Giuseppe Comi

Copyright (c) 2020 Bruna M. Rodrigues et al. This is an open access article distributed under the Creative Commons Attribution License, which permits unrestricted use, distribution, and reproduction in any medium, provided the original work is properly cited.

\begin{abstract}
High extrusion temperatures may compromise the functionality of probiotics in dry food. This study aimed to (i) evaluate the effects of two types of microencapsulation techniques, different encapsulating agents, and 120 days of storage on the viability of a commercial probiotic product and (ii) investigate fecal microbiota populations and fecal characteristics of adult cats fed with diets supplemented with probiotics. Three experimental treatments were evaluated: T1, commercial feed (control); T2, commercial kibbles coated with probiotics; and T3, commercial feed supplemented with freeze-dried probiotics and fructooligosaccharides. Fructooligosaccharides and gum arabic were used as encapsulating agents for freeze drying and spray drying and a pool containing Lactobacillus acidophilus, Lactobacillus casei, Lactobacillus lactis, Bifidobacterium bifidum, Enterococcus faecium, and Saccharomyces cerevisiae as a probiotic. Diets were provided to 18 adult cats for 20 days. Feed samples were evaluated microbiologically, and feces were characterized according to their microbial content, $\mathrm{pH}$, and fecal score. Freeze drying was more effective in maintaining microbial viability. Microcapsules prepared using fructooligosaccharides as encapsulants had the highest bacterial count: $8.74 \mathrm{log}$ CFU/g of lactic acid bacteria and $8.75 \mathrm{log}$ CFU/g of enterococci. Probiotics and synbiotics positively modulated $(P<0.05)$ the fecal microbiota of cats, increasing the lactic acid bacteria counts from 3.65 to 4.87 and $5.07 \mathrm{log}$ CFU/g, respectively. Microbial viability decreased significantly $(P<0.05)$ after storage, demonstrating the need for effective protection mechanisms against extrinsic agents. In conclusion, the supplementation of cat diets with probiotics positively affected the gut microbiota. However, the results reinforce that probiotic microorganisms must be incorporated into the animal feed via effective mechanisms to withstand harsh processing conditions and storage.
\end{abstract}

\section{Introduction}

Cats and dogs are often considered more than household pets; they are esteemed family members. Over the years, not only their population has grown immensely but also the interest in animal health and well-being has grown immensely (Grześkowiak et al.) [1]. Recent efforts have focused on the development of functional foods for pets, such as probiotics, which are live microorganisms that confer health benefits to the host when ingested in adequate quantities (Hill et al.) [2]. The composition of animal gut microbiota may be negatively impacted by antibiotics, gastrointestinal infections, changes in diet, and weaning (Vezquez-Mendonza et al.) [3]. Probiotics have been widely used for the prevention and treatment of disorders and diseases, ranging from allergies to acute gastroenteritis. They have shown a great potential for the control of overweight, urogenital tract infection, and parasitic gastritis, but further research is needed to confirm these applications (Grześkowiak et al.) [1]. 
The microorganisms most used as probiotics are those belonging to the group of Gram-positive bacteria, that present the outermost portion of the cell wall composed of peptidoglycans and lipoteichoic acid and are more porous (Lactobacillus, Streptococcus, Lactococcus, Pediococcus, Enterococcus, Bifidobacterium, $\mathrm{Ba}$ cillus, and Clostridium) (de Melo et al.) [4], Gram negative bacteria, that have in addition to the peptidoglycan, a layer composed of lipopolysaccharides, lipoproteins, and proteins, which act as a physical barrier (nonpathogenic Escherichia coli) (Dai et al.) [5], and and yeast (Saccharomyces) (Vieira et al.) [6]. In cats, the predominant bacteria come from the phylum Firmicutes, which contains microorganisms such as Bacillus, Enterococcus, and Lactobacillus (Handl et al.) [7], being generally Gram-positive microorganisms.

For functional foods containing probiotics to be eligible to make health claims, microorganisms must be able to resist the processing operations, the handling, the storage, and finally, the passage through the gastrointestinal tract (Souza et al.) [8]. In the pet food industry, processing is a critical determinant of bacterial viability. High temperatures $\left(150-160^{\circ} \mathrm{C}\right)$ are required for feed extrusion, which leads to the elimination of microorganisms (Nakandakare et al.) [9].

Few studies have been published on the quality of probiotic products for pets or the ability of microorganisms to survive the digestion process. Dzanis [10] evaluated cat and dog food products containing probiotics and found that microorganisms were absent or present at lower concentrations than those reported by manufacturers. This discrepancy may be due to environmental factors affecting microorganism viability.

To avoid loss of probiotic viability during processing, storage, and digestion, the industry has been seeking alternatives to protect probiotic microorganisms. An interesting strategy is microencapsulation, a process by which probiotics can be covered by microsized encapsulants. Encapsulants are typically insoluble in acidic media but soluble in alkaline media, favoring the release of core contents in the intestine.

In view of the potential benefits of probiotics to intestinal health and the constant search for improved animal health and welfare, we aimed to evaluate the resistance of a commercial probiotic to microencapsulation and its viability during 120 days of storage. A second aim was to evaluate changes in fecal microbiota and fecal characteristics of adult cats fed with diets containing probiotics.

\section{Materials and Methods}

Experimental procedures were approved by the Animal Ethics Committee (CEUA) of the State University of Maringá (under protocol number 3211300517). Two experiments were carried out to evaluate (i) the effects of microencapsulation and storage on probiotic viability and (ii) alteration of fecal microbiota and fecal characteristics of domestic cats fed with diets containing probiotics.
2.1. Experiment I: Determination of Probiotic Viability after Microencapsulation and Storage. A commercial probiotic containing $10^{9}$ colony-forming units (CFU)/g of Lactobacillus acidophilus, Lactobacillus casei, Lactobacillus lactis, Bifidobacterium bifidum, Enterococcus faecium, and Saccharomyces cerevisiae was used. Gum arabic (Fibregum ${ }^{\mathrm{TM}}$, CNI Colloides Naturels International, São Paulo, Brazil) and fructooligosaccharides (FOS) (Fosvita, Vitafor, Araçoiaba da Serra, Brazil) were used as encapsulating agents; trehalose (6138-23-4, Sigma-Aldrich, St. Louis, USA) was used as a thermoprotectant for spray drying; and reconstituted skimmed milk (Molico, Nestlé ${ }^{\circledR}$ ) diluted in $20 \%$ glycerol was used as a cryoprotectant for freeze drying.

Microorganisms were activated prior to microencapsulation by mixing $2 \%$ of probiotics in $100 \mathrm{ml}$ of de Man, Rogosa, and Sharpe (MRS) broth (HiMedia ${ }^{\mathrm{TM}}$ Laboratories, Mumbai, India) and Brain Heart Infusion (BHI) broth (HiMedia $^{\text {TM }}$ Laboratories, Mumbai, India) in an Erlenmeyer flask at $37^{\circ} \mathrm{C}$ for $24 \mathrm{~h}$. Subsequently, the mixture was incubated with yeast extract peptone dextrose (YEPD) broth (HiEncap $^{\text {тм }}$ YEPD, HiMedia Laboratories, Mumbai, India) at $26^{\circ} \mathrm{C}$ for $24 \mathrm{~h}$ in a conventional oven (1399, Pramel ${ }^{\circledR}$, Campo Bom, Brazil). The contents were transferred to Falcon tubes, centrifuged (Excelsa Baby I-206, Fanem ${ }^{\circledR}$, São Paulo, Brazil) at $6000 \mathrm{rpm}$ for $10 \mathrm{~min}$ at room temperature and then washed twice with sterile water (Liserre, Ré, and Franco) [11]. The bacterial colony was resuspended in $0.2 \mathrm{ml}$ of sterile water.

A solution containing $600 \mathrm{ml}$ of $0.05 \mathrm{M}$ phosphatebuffered saline (PBS, $\mathrm{pH} 7.6$ ), $1 \%$ of activated microorganisms, $2 \%$ of trehalose, and $2 \%$ of FOS was spray dried (Mini spray dryer B-191, Büchi Labortechnik AG, Flawil, Switzerland) at inlet air temperature of $175^{\circ} \mathrm{C}$ and at outlet air temperature of $100^{\circ} \mathrm{C}$.

Three solutions (S1, S2, and S3) were prepared for freeze drying, differing in the type of encapsulating agent (2\% gum arabic, $2 \%$ FOS, and $2 \%$ gum arabic $+2 \%$ FOS, respectively). Solutions were composed of $1 \%$ of activated microorganisms, $10 \%$ of the cryoprotective solution (20\% reconstituted skimmed milk), and $2 \%$ of the respective encapsulant in $150 \mathrm{ml}$ of $0.05 \mathrm{M}$ PBS (saline phosphate buffer) ( $\mathrm{pH} \mathrm{7.6).}$ Solutions were mixed with a magnetic stirrer (78HW-1, Biomixer ${ }^{\circledR}$, São Paulo, Brazil) for $5 \mathrm{~min}$, then frozen at $-20^{\circ} \mathrm{C}$, and freeze dried (Liotop L101, Liobras, São Carlos, Brazil) for $48 \mathrm{~h}$.

The commercial probiotic supplement and microcapsules were examined by scanning electron microscopy. Probiotic viability after microencapsulation was determined by plate counting. Microcapsules were added to $0.05 \mathrm{M}$ PBS (pH 7.6) at $0.01 \mathrm{~g} / \mathrm{ml}$, then stirred at $150 \mathrm{rpm}$, $37^{\circ} \mathrm{C}$, for $5 \mathrm{~min}$ (Grosso and Favaro-Trindade) [12]. Solutions were then diluted in $9 \mathrm{ml}$ of peptone water and seeded in Petri dishes containing MRS agar for Lactobacillus and Bifidobacterium growth; M17 agar for Enterococcus growth (HiMedia Laboratories, Mumbai, India); and YEPD for Saccharomyces growth at $37^{\circ} \mathrm{C}$ for $48-72 \mathrm{~h}$. Colonies were counted using a digital counter (CP600 Plus, Phoenix Luferco ${ }^{\circledR}$, São Paulo, Brazil), and the results were expressed as $\log \mathrm{CFU/g}$. 
Microcapsules were subjected to in vitro digestion to evaluate their resistance to passage through the stomach and small intestine. Digestibility coefficients were determined according to the method of Hervera et al. [13]. In short, $1 \mathrm{~g}$ of sample was homogenized in $25 \mathrm{ml}$ of $0.1 \mathrm{M} \mathrm{PBS}$ ( $\mathrm{pH}$ 6). The solution received the addition of $10 \mathrm{ml}$ of $0.2 \mathrm{M} \mathrm{HCl}$ (hydrochloric acid), and the $\mathrm{pH}$ was adjusted to 2 using $1 \mathrm{M}$ $\mathrm{HCl}$ and $1 \mathrm{M} \mathrm{NaOH}$. Then, $1 \mathrm{ml}$ of a pepsin solution containing $10 \mathrm{mg}$ of pepsin $(3651 \mathrm{U} / \mathrm{mg})$ was added. Samples were incubated in the water bath (MA093, Marconi ${ }^{\circledR}$, São Paulo, Brazil) at $39^{\circ} \mathrm{C}$ for $2 \mathrm{~h}$ under constant agitation.

After incubation, flasks were cooled and received an addition of $10 \mathrm{ml}$ of $0.2 \mathrm{M}$ PBS ( $\mathrm{pH} 6.8$ ) and $5 \mathrm{ml}$ of $0.6 \mathrm{M}$ $\mathrm{NaOH}$. The $\mathrm{pH}$ was adjusted to 6.8 using $\mathrm{HCl}$ and $\mathrm{NaOH}$ solutions. Then, $1 \mathrm{ml}$ of pancreatin solution containing $100 \mathrm{mg}$ of pancreatin powder was added. Samples were incubated in the water bath, at $39^{\circ} \mathrm{C}$, for $4 \mathrm{~h}$ under constant agitation. After this period, solutions were seeded in Petri dishes containing MRS, M17, or YEPD and incubated for $48 \mathrm{~h}$, at $35^{\circ} \mathrm{C}$, which is the ideal temperature to for the growth of lactic acid bacteria, and $26^{\circ} \mathrm{C}$, which is optimal for the yeast.

Three experimental treatments were obtained using a commercial feed (Table 1); T1, commercial feed (control); T2, commercial feed and probiotics; and T3, commercial feed and freeze-dried probiotics with FOS. The experimental diets were coated with $4.5 \%$ of poultry oil and $2.0 \%$ of liquid palatant (Dtech 12L, SPF Palatability, Descalvado, Brazil). In $\mathrm{T} 2$, the probiotics ( $2 \mathrm{~g} /$ cat day) were added by coating, and in T3, the same probiotic dose was added, plus FOS $(1 \mathrm{~g} / \mathrm{cat}$ day), as recommended by the manufacturer for better adhesion. The feed was later provided to the animals for 20 days, and samples of $25 \mathrm{~g}$ were used to evaluate the storage time for 120 days.

Sanitized polyethylene packs containing $25 \mathrm{~g}$ of feed samples were stored in the dark at room temperature $\left(25^{\circ} \mathrm{C}\right)$ for 120 days. For the determination of microbiological parameters, $25 \mathrm{~g}$ of feed was diluted in $225 \mathrm{ml}$ of peptone water and then serially diluted in test tubes containing $9 \mathrm{ml}$ of peptone water; finally the feed was seeded in Petri dishes containing MRS, M17, or YEPD agar.

Results of microbial viability and digestibility assays were subjected to analysis of variance (ANOVA), followed by Tukey's test at $P<0.05$ using SAS version 9 (SAS Institute, North Carolina, USA).

\subsection{Experiment II: Analysis of Fecal Microbiota and Fecal} Characteristics of Adult Cats. Eighteen castrated cats (males, $n=9$; females, $n=9$ ) weighing $3.8 \pm 0.56 \mathrm{~kg}$ and aged $3 \pm 0.84$ years were used in this study. The cats were divided between the three experimental treatments: T1, commercial feed (control); T2, commercial feed and probiotics; and T3, commercial feed and freeze-dried probiotics with FOS, with six animals per treatment, equally distributed between treatments in relation to sex and average weight. A randomized block design ( 2 blocks and 6 animals per treatment) was used. The animal feed was prepared in the first week of the experiment and stored an amount enough for the supply
TABLE 1: Diet composition.

\begin{tabular}{|c|c|}
\hline Ingredient & $\%$ of feed \\
\hline Corn grain & 30.40 \\
\hline Poultry meal & 29.00 \\
\hline Soybean meal $45 \%$ & 11.00 \\
\hline Brewers' rice & 7.00 \\
\hline Fish meal $61 \%$ & 5.00 \\
\hline Wheat bran & 7.00 \\
\hline Poultry oil & 4.50 \\
\hline Liquid palatant & 2.00 \\
\hline Beet pulp & 1.00 \\
\hline Yeast extract & 0.80 \\
\hline Sodium chloride & 0.56 \\
\hline Flaxseed & 0.40 \\
\hline Vitamin-mineral premix ${ }^{1}$ & 0.40 \\
\hline Calcium propionate $^{2}$ & 0.15 \\
\hline Sodium hexametaphosphate ${ }^{3}$ & 0.10 \\
\hline DL-Methionine & 0.10 \\
\hline Odor adsorbent (Yucca schidigera extract) & 0.08 \\
\hline Mycotoxin adsorbent & 0.05 \\
\hline Chelated zinc & 0.04 \\
\hline Urinary acidifier ${ }^{4}$ & 0.40 \\
\hline Synthetic antioxidant ${ }^{5}$ & 0.02 \\
\hline Metabolizable energy & $3500 \mathrm{kcal} \cdot \mathrm{kg}^{-1}$ \\
\hline
\end{tabular}

Guaranteed levels: moisture, 12\% (max.); crude protein, 30\% (min.); ethereal extract, $10 \%$ (min.); fibrous matter, $3.5 \%$ (max.); mineral matter, $8.5 \%$ (max.); calcium, $0.9 \%$ (min.); calcium, $1.8 \%$ (max.); phosphorus: $0.9 \%$ (min.); linolenic acid: $2,500 \mathrm{mg} / \mathrm{kg}$ (min.); linoleic acid $25 \mathrm{~g} / \mathrm{kg}$ (max.); saponin, $4 \mathrm{mg} / \mathrm{kg}$ (min.). ${ }^{1}$ The following was provided per kilogram in the diet: vitamin A, 10,000 IU; vitamin D, 720 IU; vitamin E, $48 \mathrm{IU}$; vitamin $\mathrm{K}$, $0.80 \mathrm{mg}$; vitamin $\mathrm{B}_{1}, 5.6 \mathrm{mg}$; vitamin $\mathrm{B}_{2}, 6 \mathrm{mg}$; vitamin $\mathrm{B}_{6}, 4.8 \mathrm{mg}$; vitamin $\mathrm{B}_{12}, 22 \mathrm{mg}$; pantothenic acid, $6 \mathrm{mg}$; folic acid, $0.80 \mathrm{mg}$; copper, $5 \mathrm{mg}$; iron, $80 \mathrm{mg}$; manganese, $8 \mathrm{mg}$; iodine, $0.60 \mathrm{mg}$; zinc, $80 \mathrm{mg}$; selenium, $0.10 \mathrm{mg}$; biotin, $0.08 \mathrm{mg}$; niacin, $64 \mathrm{mg}$; taurine, $1,000 \mathrm{mg}$; choline, $2,400 \mathrm{mg} .{ }^{2} \mathrm{An}-$ tifungal agent. ${ }^{3}$ For tartar control. ${ }^{4}$ Propionic acid. ${ }^{5}$ Butylated hydroxyanisole (BHA) and butylated hydroxytoluene (BHT).

of animals during the period of 20 days. The experiment lasted 20 days, with 15 days of adaptation to the diet and 5 days of feces collection.

The amount of feed supplied was calculated according to the energy requirements of adult cats, as recommended by the National Research Council [14]. During the adaptation period, cats were housed in a $49 \mathrm{~m}^{2}$ cattery with ad libitum access to water. Cats were housed in individual metal cages $(0.5 \times 0.5 \times 0.6 \mathrm{~m})$ for feeding, which occurred twice a day (8:00-10:00 a.m. and 2:00-4:00 p.m.). During the fecal collection period, cats were permanently kept in individual metal cages. Leftover diet was collected and weighed using a digital balance (Prix 3 fit, Toledo do Brazil, São Bernardo do Campo, Brazil).

Regarding the collection period, feces were collected on days 0,2 , and 4 . Fecal $\mathrm{pH}$ was determined by diluting $4 \mathrm{~g}$ of fresh feces in $10 \mathrm{ml}$ of distilled water and then measuring the $\mathrm{pH}$ with a digital $\mathrm{pH}$ meter (DM20, Digicrom Analytic Ltda, São Paulo, Brazil) (Walter et al.) [15].

Fecal samples were scored according to Carciofi et al. [16], using the following scoring system: 0 , liquid feces; 1 , pasty and formless feces; 2 , soft feces that take on the shape of the container; 3 , soft, moist feces that adhere to the container; 4 , well-formed, dry feces that do not adhere to the container; and 5, well-formed, hard, dry feces. 
For the evaluation of fecal microbiota, $1 \mathrm{ml}$ of feces was diluted in $99 \mathrm{ml}$ of peptone water, then rediluted in $9 \mathrm{ml}$ of peptone water, plated on MRS agar to determine lactic acid bacteria counts and, finally, plated on MacConkey agar (HiMedia Laboratories, Mumbai, India) to determine total coliform counts. Plates were incubated at $35^{\circ} \mathrm{C}$ for $48 \mathrm{~h}$, and colonies were counted using a digital counter (CP600 Plus, Phoenix Luferco ${ }^{\circledR}$, São Paulo, Brazil).

Data were subjected to ANOVA, followed by contrast analysis and Tukey's test at $P<0.05$. Statistical analyses were carried out using SAS version 9 (SAS Institute, North Carolina, USA).

\section{Results}

3.1. Experiment I: Effects of Microencapsulation and Storage on Microbial Viability. The commercial probiotic contained $8.25 \log \mathrm{CFU} / \mathrm{g}$ of lactobacilli, 8.27 log CFU/g of enterococci, and $8.25 \log \mathrm{CFU} / \mathrm{g}$ of yeasts. Although spray drying produced rounded, uniform, and smooth capsules (Figure 1), microbial viability was not maintained. Freeze drying, in contrast, was effective in maintaining the viability $(P<0.0001)$ but did not produce well-rounded, smooth microcapsules (Figure 2).

The lowest microbial counts were observed in microcapsules prepared using both gum arabic and FOS as encapsulating agents, whereas the highest lactobacilli and enterococci counts were obtained using only FOS as encapsulant $(P<0.0001)$ (Table 2$)$.

Microbial viability reduced sharply after simulated digestion (Table 2). The lowest reduction was observed in microcapsules containing only probiotics: Lactobacilli reduced by $11.86 \%$, Enterococci by $12.70 \%$, and yeasts by $12.97 \%$. Microcapsules prepared with gum arabic had the highest viability loss (up to 4.32-log reduction) (Table 2).

Overall, microcapsules containing probiotics and FOS showed the best viability results and were therefore added to commercial feed for further assays.

A significant loss in microbial viability in experimental feeds $(P<0.0001)$ was observed after 120 days of storage (Table 3). Viability loss was higher in T2 (commercial feed supplemented with probiotics), with $35.00 \%$ reduction in lactobacilli, $30.17 \%$ in enterococci, and $36.13 \%$ in yeasts. In T3 (commercial feed supplemented with freeze-dried probiotics and FOS), lactobacilli, enterococci, and yeasts were reduced by $21.32 \%, 21.18 \%$, and $19.02 \%$, respectively (Table 3).

We estimated that the loss in microbial viability of the commercial probiotic supplement after 7 months of storage would be $1.63 \log$ CFU/g for Lactobacilli, $1.13 \log \mathrm{CFU} / \mathrm{g}$ for Enterococci, and $1.24 \log \mathrm{CFU} / \mathrm{g}$ for yeasts (Table 4).

\subsection{Experiment II: Fecal Microbiota and Fecal Characteristics} of Adult Cats. During the second experimental period, the average daily feed consumption was 56, 56, and $54 \mathrm{~g} /$ day, for control treatment (T1), probiotic-supplemented feed (T2), and pre- and probiotic-supplemented feed (T3), respectively. These results indicate that, on average, cats consumed the probiotic microorganisms dose of $10^{6} \mathrm{CFU} / \mathrm{g}$ of feed, which was within the limits recommended by Roy [17], who describes the concentration of probiotics in products as $10^{6} \mathrm{CFU} / \mathrm{g}$, in order to obtain the desired clinical effects.

There was a significant difference $(P<0.0001)$ in fecal Lactobacillus counts and $\mathrm{pH}$ between treatments (Table 5). FOS was found to have a positive effect $(P<0.05)$ on the survival of beneficial bacteria. Total coliform counts decreased throughout the stool collection period (days 0,2 , and 4). Contrast analysis revealed that the total coliform counts were significantly lower $(P<0.05)$ on the second day of feces collection (Table 5).

No differences $(P>0.05)$ in fecal score were observed between treatments or collection days; fecal scores were always within the normal range (between 3 and 4) for domestic cats (Carciofi et al.) [13].

\section{Discussion}

4.1. Experiment I: Effect of Microencapsulation and Storage on Microbial Viability. The commercial probiotic supplement initially contained high concentrations $\left(10^{8} \mathrm{CFU} / \mathrm{g}\right)$ of lactobacilli, enterococci, and yeasts, but no viable cells were observed after spray drying. These findings are in contrast with the results of Silva et al. [18], who studied the spraydrying microencapsulation of Bifidobacterium animalis and L. acidophilus and reported that this process did not decrease microbial viability. As noted in our study, Silva et al. [18] also observed that microencapsulation produced highly spherical, well-coated capsules that protected probiotic bacteria from environmental conditions, such as $\mathrm{pH}$, storage, and in vitro simulation of the passage resistance through the gastrointestinal tract. Ananta et al. [19] showed that the higher the drying temperature of L. rhamnosus by spray drying, the lower the survival rate. Nunes et al. [20] also observed a reduction in bacterial viability with temperature in the microencapsulation of B. animalis $\mathrm{Bb}-12$ and L. acidophilus La- 5 by spray drying $\left(10^{\circ} \mathrm{C}\right.$ to $\left.140^{\circ} \mathrm{C}\right)$. A reduction of $2.7 \mathrm{log}$ $\mathrm{CFU} / \mathrm{g}$ was observed immediately after spray drying at $140^{\circ} \mathrm{C}$. So, in our study, the high inlet temperature of spray drying $\left(175^{\circ} \mathrm{C}\right)$ probably led to microbial unfeasibility after drying.

Spray drying is a rapid and efficient technique capable of producing large amounts of dry material; however, with this technique, the cell viability is reduced (Sunny-Roberts and Knorr) [21]. Protective agents can be used to minimize this problem. Trehalose, a glucose disaccharide, is an effective thermoprotectant at low and high temperatures (SunnyRoberts and Knorr) [20]. Studying the effects of trehalose on S. cerevisiae, Trevisol et al. [22] found that this sugar increases not only the stress resistance of yeast cells but also their fermentation capacity. Su et al. [23] obtained a survival rate of $5 \%$ after spray drying L. rhamnosus GG at an inlet air temperature of $98^{\circ} \mathrm{C}$ and at an outlet air temperature of $65^{\circ} \mathrm{C}$, using trehalose as thermoprotectant. When calcium was added to the feed solution as additional thermal protection, the survival rate increased to $30 \%$. These data reinforce the importance of choosing an appropriate thermoprotectant to preserve microbial viability during spray drying. In this study, 


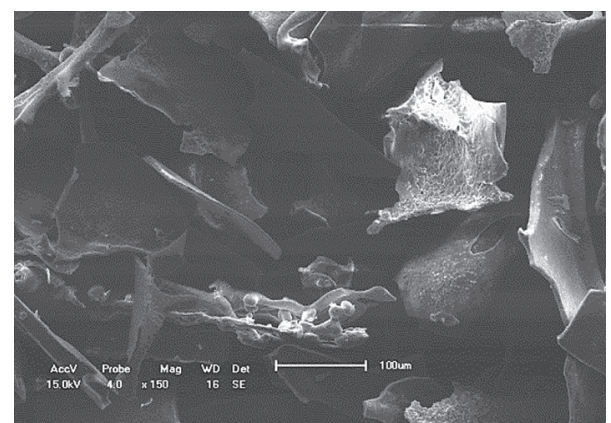

(a)

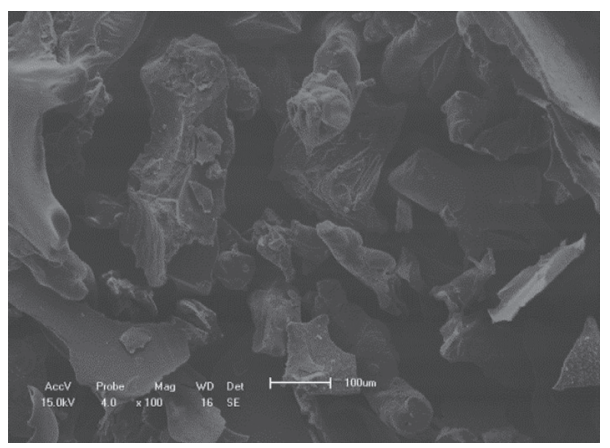

(c)

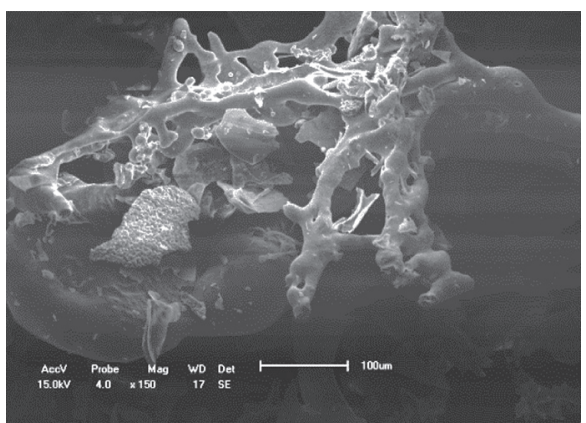

(b)

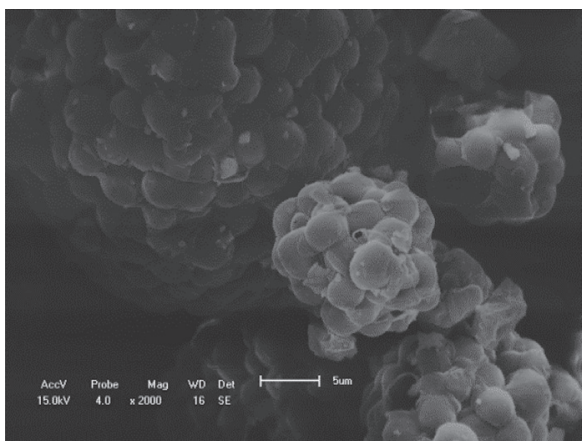

(d)

FIGURE 1: Scanning electron microscopy images of lyophilized microcapsules (A-C) and a commercial probiotic supplement (D). (a) Probiotic microcapsule with fructooligosaccharides as encapsulant (150x magnification); (b) probiotic microcapsule with gum arabic and fructooligosaccharides as encapsulants (100x magnification); (c) probiotic microcapsule with gum arabic as encapsulant (100x magnification); (d) commercial probiotic (2000x magnification).

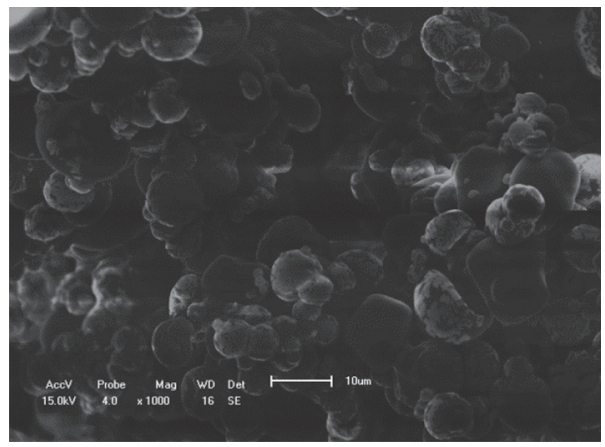

(a)

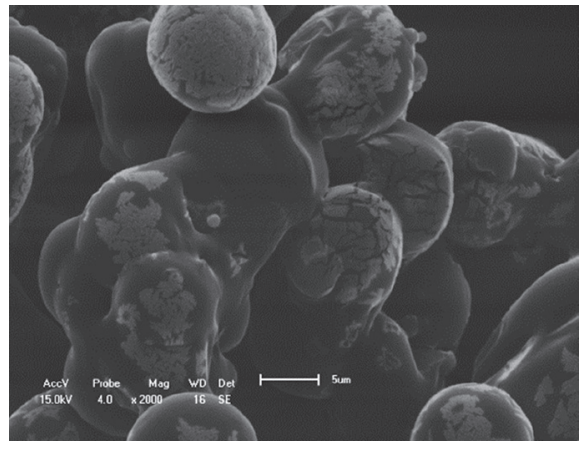

(b)

Figure 2: Scanning electron microscopy images of microcapsules prepared by spray drying. (a) 1000x magnification; (b) 2000x magnification.

TABLE 2: Microbial count (log CFU/g) of a commercial probiotic product and lyophilized probiotics before and after in vitro digestion.

\begin{tabular}{lccccccccccccc}
\hline \multirow{2}{*}{ Microorganism } & \multicolumn{4}{c}{ Before in vitro digestion } & \multicolumn{4}{c}{ After in vitro digestion } \\
& Prob & S1 & S2 & S3 & SEM & $P$ & Prob & S1 & S2 & S3 & SEM & $P$ \\
\hline Lactobacilli & $8.25^{\mathrm{b}}$ & $7.71^{\mathrm{c}}$ & $7.52^{\mathrm{d}}$ & $8.74^{\mathrm{a}}$ & 0.039 & $<0.0001$ & $7.28^{\mathrm{a}}$ & $3.67^{\mathrm{b}}$ & $2.24^{\mathrm{c}}$ & $3.67^{\mathrm{b}}$ & 0.039 & $<0.0001$ \\
Enterococci & $8.27^{\mathrm{b}}$ & $8.10^{\mathrm{b}}$ & $7.86^{\mathrm{c}}$ & $8.75^{\mathrm{a}}$ & 0.051 & $<0.0001$ & $7.22^{\mathrm{a}}$ & $3.78^{\mathrm{c}}$ & $3.73^{\mathrm{c}}$ & $4.65^{\mathrm{b}}$ & 0.051 & $<0.0001$ \\
Yeasts & $8.25^{\mathrm{a}}$ & $<1.00^{\mathrm{b}}$ & $<1.00^{\mathrm{b}}$ & $<1.00^{\mathrm{b}}$ & 0.034 & $<0.0001$ & $7.18^{\mathrm{a}}$ & $<1.00^{\mathrm{b}}$ & $<1.00^{\mathrm{b}}$ & $<1.00^{\mathrm{b}}$ & 0.034 & $<0.0001$ \\
\hline
\end{tabular}

Means in a row followed by different lowercase letters differ by Tukey's test $(P<0.05)$. Prob: commercial probiotic product; S1: solutions containing $1 \%$ of activated microorganisms $+10 \%$ of the cryoprotective solution $+2 \%$ of the gum arabic, S2: solutions containing $1 \%$ of activated microorganisms $+10 \%$ of the cryoprotective solution $+2 \%$ FOS $+2 \%$ gum Arabic, and S3: solutions containing $1 \%$ of activated microorganisms $+10 \%$ of the cryoprotective solution $+2 \%$ FOS; SEM: standard error of the mean. 
TABle 3: Microbial viability (log CFU/g) in feed during storage at room temperature.

\begin{tabular}{|c|c|c|c|c|c|c|}
\hline \multirow{2}{*}{ Storage (day) } & \multicolumn{2}{|c|}{ Treatment } & \multirow{2}{*}{ SEM } & \multicolumn{3}{|c|}{$P$ value } \\
\hline & $\mathrm{T} 1$ & $\mathrm{~T} 2$ & & Treatment & Storage & Treatment $\times$ storage \\
\hline \multicolumn{7}{|l|}{ Lactobacilli } \\
\hline 0 & $6.52^{\mathrm{a}}$ & $6.05^{\mathrm{b}}$ & 0.027 & \multirow{7}{*}{$<0.0001$} & \multirow{7}{*}{$<0.0001^{1}$} & \multirow{7}{*}{$<0.0001$} \\
\hline 7 & $5.99^{\mathrm{b}}$ & $5.28^{\mathrm{c}}$ & 0.027 & & & \\
\hline 15 & $5.33^{\mathrm{c}}$ & $5.26^{\mathrm{c}}$ & 0.027 & & & \\
\hline 30 & $5.13^{\mathrm{d}}$ & $4.94^{\mathrm{e}}$ & 0.027 & & & \\
\hline 60 & $4.94^{\mathrm{e}}$ & $4.97^{\mathrm{e}}$ & 0.027 & & & \\
\hline 90 & $4.44^{\mathrm{h}}$ & $4.86^{\mathrm{f}}$ & 0.027 & & & \\
\hline 120 & $4.24^{\mathrm{i}}$ & $4.76^{\mathrm{g}}$ & 0.027 & & & \\
\hline \multicolumn{7}{|l|}{ Enterococci } \\
\hline 0 & $6.63^{\mathrm{a}}$ & $6.28^{\mathrm{b}}$ & 0.041 & \multirow{7}{*}{$<0.0001$} & \multirow{7}{*}{$<0.0001^{2}$} & \multirow{7}{*}{$<0.0001$} \\
\hline 7 & $6.32^{\mathrm{b}}$ & $5.82^{\mathrm{d}}$ & 0.041 & & & \\
\hline 15 & $5.92^{\mathrm{cd}}$ & $5.67^{\mathrm{e}}$ & 0.041 & & & \\
\hline 30 & $5.85^{\mathrm{d}}$ & $5.97^{\mathrm{c}}$ & 0.041 & & & \\
\hline 60 & $5.36^{\mathrm{f}}$ & $5.60^{\mathrm{e}}$ & 0.041 & & & \\
\hline 90 & $5.15^{\mathrm{g}}$ & $5.02^{\mathrm{h}}$ & 0.041 & & & \\
\hline 120 & $4.63^{\mathrm{i}}$ & $4.95^{\mathrm{h}}$ & 0.041 & & & \\
\hline \multicolumn{7}{|l|}{ Yeasts } \\
\hline 0 & $6.56^{\mathrm{a}}$ & $6.10^{\mathrm{b}}$ & 0.037 & \multirow{7}{*}{0.3030} & \multirow{7}{*}{$<0.0001^{3}$} & \multirow{7}{*}{$<0.0001$} \\
\hline 7 & $6.17^{\mathrm{b}}$ & $5.66^{\mathrm{d}}$ & 0.037 & & & \\
\hline 15 & $5.77^{\mathrm{c}}$ & $5.43^{\mathrm{e}}$ & 0.037 & & & \\
\hline 30 & $5.15^{\mathrm{f}}$ & $5.13^{\mathrm{f}}$ & 0.037 & & & \\
\hline 60 & $5.01^{\mathrm{g}}$ & $5.01^{\mathrm{g}}$ & 0.037 & & & \\
\hline 90 & $4.69^{\mathrm{h}}$ & $5.12^{\mathrm{f}}$ & 0.037 & & & \\
\hline 120 & $4.19^{\mathrm{i}}$ & $4.94^{\mathrm{g}}$ & 0.037 & & & \\
\hline
\end{tabular}

Means in a column followed by different lowercase letters differ by Tukey's test $(P<0.05)$. T1: feed supplemented with a commercial probiotic product; T2: feed supplemented with freeze-dried probiotics and fructooligosaccharides; SEM: standard error of the mean. ${ }^{1} \hat{y}=5.735-0.012 x\left(r^{2}=66.99 \%\right) .{ }^{2} \hat{y}=6.218-$ $0.012 x\left(r^{2}=86.08 \%\right){ }^{3} \hat{y}=5.922-0.012 x\left(r^{2}=71.17 \%\right)$.

TABle 4: Microbial viability (log CFU/g) of a commercial probiotic supplement after 7 months of storage.

\begin{tabular}{lccc}
\hline Microorganism & May 2017 & December 2017 & \% Reduction \\
\hline Lactobacilli & 8.28 & 6.65 & 19.66 \\
Enterococci & 8.22 & 7.09 & 13.75 \\
Yeasts & 8.22 & 6.98 & 15.09 \\
\hline
\end{tabular}

trehalose was not an efficient protective agent, probably because of the high temperatures used (inlet air temperature of $175^{\circ} \mathrm{C}$ and outlet air temperature of $100^{\circ} \mathrm{C}$ ). Postdrying viability also depends on the intrinsic stress tolerance of probiotic microorganisms, chemical and physical characteristics of encapsulating agents, processing time and pressure, and storage conditions (Chàvez and Ledeboer) [24].

Drying at temperatures close to $0^{\circ} \mathrm{C}$ is known to enhance microbial stability by reducing the rates of chemical reactions (Nag et al.) [25]. Accordingly, we found that the freezedrying process preserved the viability of Lactobacilli and Enterococci (Table 2). The microbial viabilities obtained in this study (about 90\%) are higher than those reported by Zayed and Ross [26], when assessing the cryoprotectant properties of milk during the freeze drying process of Lactobacillus salivarius (about 22\%). These results may be attributed to the cryoprotective effect of FOS and gum arabic. Jantarathin et al. [27] produced microcapsules of $L$. acidophilus, inulin, and sodium alginate by extrusion and obtained $88.19 \%$ of cell viability. According to Aslan-Tontul and Erbas [28], the combination of probiotics and prebiotics can improve the resistance of microorganisms to processing conditions. Romano et al. [29] reported that oligosaccharides have a protective effect on probiotics in feed matrices.

Yeast cells are particularly sensitive to freeze drying. Miyamoto-Shinohara et al. [30] investigated the survival rate of different microorganisms during freeze-drying processes and found that $S$. cerevisiae showed a maximum viability of $10 \%$, much lower than that observed for other Gram-negative and Gram-positive bacteria (about 80\%).

Freeze-dried probiotics showed considerable loss of viability under simulated gastrointestinal conditions. These data are in agreement with the results of Xu et al. [31] for $L$. casei encapsulated by extrusion followed by freeze drying. The authors observed a relatively low viability reduction (0.41 log CFU/g) after drying, but a significant loss of viability after in vitro gastrointestinal digestion (2.24log CFU/ g). Counterintuitive to these results was the finding of Garcia-Hernandez et al. [32] that probiotic bacteria commonly used in animal feed are greatly resistant to simulated gastrointestinal conditions if they are not previously subjected to other environmental stresses. Thus, the high viability loss observed in this study was probably due to the consecutive stress events: freeze drying followed by hydration, exposure to acidic medium, enzymatic digestion, and alkaline medium. 
Table 5: Microbial composition (log CFU/g), fecal pH, and fecal score of cats fed with diets supplemented with probiotics.

\begin{tabular}{lccccccccccccccc}
\hline \multirow{2}{*}{ Variable } & \multicolumn{3}{c}{ Treatment } & \multirow{2}{*}{ SEM } & \multicolumn{4}{c}{$P$} & \multicolumn{3}{c}{ Contrasts } & \multicolumn{3}{c}{ Time (day) } & \multicolumn{4}{c}{ Contrasts } \\
& 1 & 2 & 3 & & & T1 $\times$ T3 & T2 $\times$ T1, T3 & 0 & 2 & 4 & & $P$ & D0 $\times$ D4 & D2 $\times$ D0, D4 \\
\hline Lactobacilli & $3.65^{\mathrm{b}}$ & $5.07^{\mathrm{a}}$ & $4.87^{\mathrm{a}}$ & 0.097 & $<0.0001$ & $<0.0001$ & $<0.0001$ & 4.42 & 4.61 & 4.54 & 0.097 & 0.3650 & NS & NS \\
Coliforms & 2.50 & 3.00 & 2.98 & 0.195 & 0.1268 & NS & NS & $3.25^{\mathrm{a}}$ & $2.31^{\mathrm{b}}$ & $2.91^{\mathrm{ab}}$ & 0.195 & $<0.05$ & NS & $<0.05$ \\
Fecal pH & $5.67^{\mathrm{b}}$ & $5.96^{\mathrm{a}}$ & $5.81^{\mathrm{ab}}$ & 0.059 & $<0.05$ & $<0.05$ & $<0.05$ & 5.78 & 5.88 & 5.82 & 0.059 & 0.4674 & NS & NS & NS \\
Fecal score & 3.22 & 3.22 & 3.11 & 0.103 & 0.6815 & NS & NS & 3.11 & 3.19 & 3.25 & 0.103 & 0.6344 & NS & NS \\
\hline
\end{tabular}

Means in a row followed by different lowercase letters differ by Tukey's test $(P<0.05)$. SEM: standard error of the mean; NS: not significant; T1: commercial feed (control); T2: commercial feed and probiotics; T3: commercial feed and freeze-dried probiotics with fructooligosaccharides; D0: day 0; D2: day 2; D4: day 4.

The probiotic supplement was found to lose viability faster when mixed with feed (Table 5), which might have been caused by the presence of antimicrobial components, $\mathrm{pH}$, and water activity in the feed. Feed mixed with probiotics had a 2-log reduction in Lactobacillus, Enterococcus, and yeast counts in 120 days of storage, whereas the probiotic supplement took 7 months to achieve a similar loss in viability.

The addition of FOS increased microbial viability in feed after 120 days of storage; that is, the FOS helped to protect probiotic microorganisms from the intrinsic antimicrobial effects of the feed. The protective properties of prebiotics were also observed by Avila-Reyes et al. [33] in the spraydrying microencapsulation of L. rhamnosus with inulin and likewise found by Desmond et al. [34] in the encapsulation of L. paracasei with gum arabic. González-Forte et al. [35] applied an inulin coating on extruded dog biscuits containing probiotic bacteria $\left(140^{\circ} \mathrm{C}, 45 \mathrm{~min}\right)$ and observed that the protective layer preserved the microbial viability for 30 days of storage.

A combination of different production techniques can be used to protect the microorganisms from environmental conditions and maintain the viability throughout shelf life. Gonçalves et al. [36] added freeze-dried probiotic microcapsules during the preparation of extruded and pelletized dog food and found that bacterial viability remained unchanged for 12 months of storage.

4.2. Experiment II: Effect of Probiotics on Fecal Microbiota and Fecal Characteristics of Adult Cats. Probiotics are considered living microorganisms whose ingestion has health benefits; however, there is no minimum concentration established for the inclusion of them in animal feed, so sufficient inclusion is recommended for microorganisms to colonize and bring benefits to the health of the host (Cho and Finocchiaro) [37]. The effectiveness of probiotic products depends on the concentration of viable cells; therefore, there is no lower limit of probiotic counts recommended for animal feed. According to the worldwide recommendation, it is necessary to specify the identification of strains on the label of the feed and the suitable levels of UFC/g. However, the minimum quantities necessary are not defined, but the product is present in an amount which is enough to exercise probiotic function, which must be proven (Brazil) [38]. It was what we noted in this study, in which treatments containing probiotics (T2) or probiotics in combination with FOS (T3) were effective in the increase of beneficial bacteria in the gastrointestinal tract (Table 5). Contrast analysis between $\mathrm{T} 1$ (control diet) and T3 confirmed the positive effect $(P<0.05)$ in increasing Lactobacillus in the beneficial gastrointestinal microbiota of cats.

There was a reduction in the enteric bacteria during the experimental period, probably because of the increase in the beneficial bacteria, which inhibited the growth of other microorganisms, particularly those not able to ferment FOS, such as E. coli and most pathogens (Hidaka et al. [39]; Russell [40]; Swanson et al. [41]; Middelbos et al. [42]). Contrast analysis revealed that total coliform counts were significantly lower on the second day of feces collection. Ritchie et al.) [43], using universal primers, observed in only $13 \%$ of fecal samples from cats the presence of Bifidobacteruim and Lactobacillus, which suggests that these microorganisms are not part of the normal microbiota of these animals, but when they used specific primers to detect Lactobacillus and Bifidobacteria in fecal samples of cats, they observed the presence of $100 \%$ and $92 \%$ of the microorganisms in the samples, respectively, so these species are naturally abundant in the cat gastrointestinal tract. Therefore, the dietary supplementation with these microorganisms or with substrates that promote their growth is able to modulate the composition of the gastrointestinal microbiota.

According to Flesch et al. [44], Lactobacilli are predominant microorganisms in the small intestine and are responsible for inhibiting the proliferation of pathogenic bacteria by competing for adhesion sites and nutrients and for producing organic acids that reduce intestinal $\mathrm{pH}$. The bifidobacteria are generally prevalent in the large intestine, and they have a beneficial role in preventing diarrhea, in addition to influence the bioavailability and the digestibility of some nutrients in the diet, by lowering the intestinal $\mathrm{pH}$ or the presence of iron lactate in the intestine. Another advantageous role is the release of several enzymes in the intestinal lumen, which acts directly on the digestion, thus increasing the absorption of various nutrients, including calcium, magnesium, and iron (Saad, 2006) [45].

According to Silva et al. [46], the probiotic effect of microorganisms is host specific. However, the most commercially available probiotics are not of canine or feline origin. The gastrointestinal tract of these animals certainly rich in microorganisms with a probiotic potential is waiting to be discovered. 
The positive effects of probiotics on animal intestinal health were confirmed by Marshall-Jones et al. [47]. The authors supplemented healthy adult cats with L. acidophilus DSM13241 and observed an increase in Lactobacillus counts in feces, accompanied by a decrease in Clostridium spp. and Enterococcus faecalis, $\mathrm{pH}$ reduction, and beneficial systemic and immunomodulatory effects in cats. In a study with dogs and cats, Bybee et al. [48] found a lower incidence of diarrhea in animals fed with diets enriched with Enterococcus faecium SF68, suggesting a positive effect of the probiotic on the gastrointestinal tract of animals. A similar beneficial effect was reported by Garcia-Mazcorro et al. [49], who administered a combination of seven probiotics bacteria (Enterococcus faecium, Streptococcus thermophilus, Bifidobacterium longum, Lactobacillus acidophilus, Lactobacillus rhamnosus, Lactobacillus plantarum, and Lactobacillus bulgaricus) and FOS to dogs and cats. High counts of probiotic bacteria, mainly Enterococcus e Streptococcus, were found in feces, and no adverse gastrointestinal effects were observed.

Gómez-Gallego et al. [50] added fermented milk containing Lactobacillus fermentum, L. rhamnosus, and $L$. plantarum to the diet of dogs suffering from acute diarrhea. The results were increased appetite, reduced vomiting, and reduced diarrhea, which are effects attributed to the $1.89 \mathrm{log}$ $\mathrm{CFU} / \mathrm{g}$ reduction in Clostridium perfringens in feces samples compared with those of the control (placebo).

Prebiotics can also modify the microbiota of dogs and cats, as made evident by the increase in lactic acid bacteria in feces samples of cats fed with diets containing probiotics and FOS. These results agree with those found by Kanakupt et al. [51], who observed an increase in Bifidobacterium spp. in the feces of cats supplemented with $0.5 \%$ FOS.

The fecal $\mathrm{pH}$ was expected to decrease with the increase in lactic acid bacteria, although in this study, there was no difference regarding the $\mathrm{pH}$ values observed in the control treatment and in the treatment supplemented with probiotic and FOS. High concentrations of probiotic bacteria may increase the levels of organic acids, which are resultant from fermentation. Organic acids reduce the $\mathrm{pH}$ of the medium, and, together with prebiotics and other antibacterial substances, such as bacteriocins, hydrogen peroxide, and enzymes, they inhibit the growth of pathogenic microorganisms (Tripathi and Giri) [52].

The fecal score is a good indicator of fecal quality, as it indicates the consistency, shape, and moisture of feces. Probiotics and synbiotics did not alter fecal score, which was maintained between 3 and 4, being considered normal. Similar results were reported by Swanson et al. [41], who supplemented dog diets with mannooligosaccharide (MOS) and FOS, and any differences in fecal quality were not observed.

The effectiveness of probiotic products depends on the concentration of viable cells and several factors influence probiotic viability in feed during processing and storage, including feed composition, microbiological parameters, and processing conditions (Thipathi and Giri) [52]. In this study, probiotic and synbiotic supplements were added to the feed only after processing, which suggests that intrinsic feed parameters, such as $\mathrm{pH}$, acidity, redox potential, and water activity, and the concentration of salt, sugar, preservatives, and artificial colorings are responsible for the considerable reduction in probiotic viability during storage.

\section{Conclusions}

The combination of probiotics and FOS improved microbial viability after freeze drying. Supplementation of cat diets with probiotic bacteria was efficient in modulating the gut microbiota. However, probiotic viability in feed decreased during the storage because of the microbial susceptibility to environmental conditions and the incompatibility between microorganisms and feed components, revealing the need for protective formulations and mild production conditions.

\section{Data Availability}

The data used to support the findings of this study are included within the article.

\section{Conflicts of Interest}

The authors declare that they have no conflicts of interest regarding the publication of this article.

\section{References}

[1] Ł Grześkowiak, A. Endo, S. Beasley, and S. Salminen, "Microbiota and probiotics in canine and feline welfare," Anaerobe, vol. 34, pp. 14-23, 2015.

[2] C. Hill, F. Guarner, G. Reid et al., "The International Scientific Association for Probiotics and Prebiotics consensus statement on the scope and appropriate use of the term probiotic," Nature Reviews Gastroenterology \& Hepatology, vol. 11, no. 8, pp. 506-514, 2014.

[3] P. Vazquez-Mendonza, M. M. M. Elghandour, P. A. Alaba et al., "Antimicrobial and bactericidal impacts of Bacillus amyloliquefaciens CECT 5940 on fecal shedding of pathogenic bacteria in dairy calves and adult dogs," Microbial Pathogenesis, vol. 114, pp. 458-463, 2018.

[4] W. C. de Melo, P. Avci, M. N. de Oliveira et al., "Photodynamic inactivation of biofilm: taking a lightly colored approach to stubborn infection," Expert Review of Anti-infective Therapy, vol. 11, no. 7, pp. 669-693, 2013.

[5] T. Dai, Y. Y. Huang, and M. R. Hamblin, "Photodynamic therapy for localized infections - state of the art," Photodiagnosis Photodyn Ther, vol. 6, no. 3-4, pp. 170-188, 2009.

[6] L. Q. Vieira, F. J. Penna, L. A. Péret Filho, and J. R. Nicoli, "Uso de probióticos na prevenção e tratamento de infecções e inflamações gastrointestinais," Revista Médica de Minas Gerais, vol. 17, no. 1-2, pp. 45-53, 2007.

[7] S. Handl, S. E. Dowd, J. F. Garcia-Mazcorro, J. M. Steiner, and J. S. Suchodolski, "Massive parallel 16S rRNA gene pyrosequencing reveals highly diverse fecal bacterial and fungal communities in healthy dogs and cats," FEMS Microbiology Ecology, vol. 76, no. 2, pp. 301-310, 2011.

[8] B. V. C. Souza, PO. Rocha, C. A. R. S. Brito, L. M. V. Galvão, and L. C. C. Nunes, "Scientific and technological prospection on microencapsulation of probiotics by spray drying," Geintec, vol. 9, pp. 4919-4928, 2019.

[9] I. B. Nakandakare, M. K. P. Iwashita, D. C. Dias, L. Tachibana, M. J. T. Ranzani-Paiva, and E. Romagosa, "Incorporação de 
probióticos na dieta para juvenis de Tilápia-do-Nilo: parâmetros hematológicos, imunológicos e microbiológicos," Boletim do Instituto de Pesca, vol. 39, pp. 121-135, 2013.

[10] D. A. Dzanis, "Scientific evaluations of popular novel ingredients, Part I e II," in Proceedings of the Production Symposium Trade Show-Pet Food Forum, pp. 11-20, Chicago, IL, USA, August 2003.

[11] A. M. Liserre, M. I. Ré, and B. D. G. M. Franco, "Microencapsulation ofBifidobacterium animalissubsp.lactisin modified alginate-chitosan beads and evaluation of survival in simulated gastrointestinal conditions," Food Biotechnology, vol. 21, no. 1, pp. 1-16, 2007.

[12] C. R. F. Grosso and C. S. Fávaro-Trindade, "Stability of free and immobilized Lactobacillus acidophilus and Bifidobacterium lactis in acidified milk and of immobilized B. lactis in yoghurt," Brazilian Journal of Microbiology, vol. 35, no. 1-2, pp. 151-156, 2004.

[13] M. Hervera, M. D. Baucells, F. Blanch, and C. Castrillo, "Prediction of digestible energy content of extruded dog food by in vitro analyses," Journal of Animal Physiology and Animal Nutrition, vol. 91, no. 5-6, pp. 205-209, 2007.

[14] National Research Council (NRC), Nutrient Requirements of Dogs and Cats, p. 398, National Academy Press, Washington, DC, USA, 2006.

[15] M. Walter, LP. Silva, and D. M. X. Perdomo, "Biological response of rats to resistent starch," Revista Instituto Adolfo Lutz, vol. 64, pp. 252-257, 2005.

[16] A. C. Carciofi, F. S. Takakura, L. D. De-Oliveira et al., "Effects of six carbohydrate sources on dog diet digestibility and postprandial glucose and insulin response," Journal of Animal Physiology and Animal Nutrition, vol. 92, no. 3, pp. 326-336, 2008.

[17] D. Roy, "Technological aspects related to the use of bifidobacteria in dairy products," Le Lait, INRA Editions, vol. 85, no. 1-2, pp. 39-56, 2005.

[18] P. T. d. Silva, L. L. M. Fries, C. R. d. Menezes et al., "Microencapsulação de probióticos por spray drying: avaliação da sobrevivência sob condições gastrointestinais simuladas e da viabilidade sob diferentes temperaturas de armazenamento," Ciência Rural, vol. 45, no. 7, pp. 1342-1347, 2015.

[19] E. Ananta, M. Volkert, and D. Knorr, "Cellular injuries and storage stability of spray-dried Lactobacillus rhamnosus GG," International Dairy Journal, vol. 15, no. 4, pp. 399-409, 2005.

[20] GL. Nunes, MH. Motta, AJ. Cichoski et al., "Encapsulation of Lactobacillus acidophilus La-5 and Bifidobacterium Bb-12 by spray drying and evaluation of its resistance in simulated gastrointestinal conditions, thermal treatments and storage conditions," Ciência Rural, vol. 48, pp. 1-11, 2018.

[21] E. O. Sunny-Roberts and D. Knorr, "The protective effect of monosodium glutamate on survival of Lactobacillus rhamnosus GG and Lactobacillus rhamnosus E-97800 (E800) strains during spray-drying and storage in trehalose-containing powders," International Dairy Journal, vol. 19, no. 4, pp. 209-214, 2009.

[22] E. T. V. Trevisol, S. C. Mannarino, E. C. A. Eleutherio, and E. C. Eleutherio, "The effect of trehalose on the fermentation performance of aged cells of Saccharomyces cerevisiae," Applied Microbiology and Biotechnology, vol. 90, no. 2, pp. 697-704, 2011.

[23] Y. Su, X. Zheng, Q. Zhao et al., "Spray drying of Lactobacillus rhamnosus GG with calcium-containing protectant for enhanced viability," Powder Technology, vol. 358, 2018.
[24] B. E. Chávez and A. M. Ledeboer, "Drying of probiotics: optimization of formulation and process to enhance storage survival," Drying Technology, vol. 25, no. 7-8, pp. 1193-1201, 2007.

[25] A. Nag, K.-S. Han, and H. Singh, "Microencapsulation of probiotic bacteria using $\mathrm{pH}$-induced gelation of sodium caseinate and gellan gum," International Dairy Journal, vol. 21, no. 4, pp. 247-253, 2011.

[26] G. Zayed and Y. H. Roos, "Influence of trehalose and moisture content on survival of Lactobacillus salivarius subjected to freeze-drying and storage," Process Biochemistry, vol. 39, no. 9, pp. 1081-1086, 2004.

[27] S. Jantarathin, C. Borompichaichartkul, and R. Sanguandeekul, "Microencapsulation of probiotic and prebiotic in alginatechitosan capsules and its effect on viability under heat process in shrimp feeding," Materials Today: Proceedings, vol. 4, no. 5, pp. 6166-6172, 2017.

[28] S. Arslan-Tontul and M. Erbas, "Single and double layered microencapsulation of probiotics by spray drying and spray chilling," LWT - Food Science and Technology, vol. 81, pp. 160-169, 2017.

[29] N. Romano, E. Tymczyszyn, P. Mobili, and A. GomezZavaglia, "Probiotics as protectants of lactic acid bacteria," Probiotics, Prebiotics and Synbiotics. Bioactive Foods in Health Promotion, Elsevier, Amsterdam, Netherlands, 2016.

[30] Y. Miyamoto-Shinohara, T. Imaizumi, J. Sukenobe, Y. Murakami, S. Kawamura, and Y. Komatsu, "Survival rate of microbes after freeze-drying and long-term storage," Cryobiology, vol. 41, no. 3, pp. 251-255, 2000.

[31] M. Xu, F. Gagné-Bourque, M.-J. Dumont, and S. Jabaji, "Encapsulation of Lactobacillus casei ATCC 393 cells and evaluation of their survival after freeze-drying, storage and under gastrointestinal conditions," Journal of Food Engineering, vol. 168, pp. 52-59, 2016.

[32] Y. García-Hernández, T. Pérez-Sánchez, R. Boucourt et al., "Isolation, characterization and evaluation of probiotic lactic acid bacteria for potential use in animal production," Research in Veterinary Science, vol. 108, pp. 125-132, 2016.

[33] S. V. Avila-Reyes, F. J. Garcia-Suarez, M. T. Jiménez, M. F. San Martín-Gonzalez, and L. A. Bello-Perez, "Protection of L. rhamnosus by spray-drying using two prebiotics colloids to enhance the viability," Carbohydrate Polymers, vol. 102, pp. 423-430, 2014.

[34] C. Desmond, R. P. Ross, E. O’Callaghan, G. Fitzgerald, and C. Stanton, "Improved survival of Lactobacillus paracasei NFBC 338 in spray-dried powders containing gum acacia," Journal of Applied Microbiology, vol. 93, no. 6, pp. 1003-1011, 2002.

[35] L. González-Forte, E. Bruno, and M. Martino, “Application of coating on dog biscuits for extended survival of probiotic bacteria," Animal Feed Science and Technology, vol. 195, pp. 76-84, 2014.

[36] M. Gonçalves, RP. Maluta, F. Dahlke, A. Maiorka, and F. A. Ávioa, "Avaliação da capacidade imunoestimulante e da estabilidade de um probiótico empregado em rações de cães," Archives of Veterinary Science, vol. 12, pp. 25-30, 2007.

[37] S. S. Cho and E. T. Finocchiaro, "Handbook of prebiotics and probiotics ingredients," Health Benefits and Food Applications, CRC Press, Boca Raton, FL, USA, 2010.

[38] Brasil Ministério da Saúde, Instrução Normativa n. 44, de 15 de dezembro de 2015. Regulamento técnico sobre aditivos para produtos destinados à alimentação animal, Dipario Oficial da União, Brasília, 2015. 
[39] H. Hidaka, M. Hirayama, T. Tokunaga, and T. Eida, "The effects of undigestible fructooligosaccharides on intestinal microflora and various physiological functions on human health," Advances in Experimental Medicine and Biology, vol. 270, pp. 105-117, 1990.

[40] T. J. Russell, The Effect of Natural Source of Non-digestible Oligosaccharides on the Fecal Microflora of the Dog and Effects on Digestion, p. 19, Friskies R \& D Center, St. Joseph: MI, USA, 1998.

[41] K. S. Swanson, C. M. Grieshop, E. A. Flickinger et al., "Supplemental fructooligosaccharides and mannanoligosaccharides influence immune function, ileal and total tract nutrient digestibilities, microbial populations and concentrations of protein catabolites in the large bowel of dogs," The Journal of Nutrition, vol. 132, no. 5, pp. 980-989, 2002.

[42] I. S. Middelbos, N. D. Fastinger, and G. C. Fahey Jr., "Evaluation of fermentable oligosaccharides in diets fed to dogs in comparison to fiber standards," Journal of Animal Science, vol. 85, no. 11, pp. 3033-3044, 2007.

[43] L. E. Ritchie, K. F. Burke, J. F. Garcia-Mazcorro, J. M. Steiner, and J. S. Suchodolski, "Characterization of fecal microbiota in cats using universal 16S rRNA gene and group-specific primers for Lactobacillus and Bifidobacterium spp," Veterinary Microbiology, vol. 144, no. 1-2, pp. 140-146, 2010.

[44] A. G. T. Flesch, A. K. Poziomyck, and D. D. C. Damin, "The therapeutic use of symbiotics," ABCD. Arquivos Brasileiros de Cirurgia Digestiva (São Paulo), vol. 27, no. 3, pp. 206-209, 2014.

[45] S. M. I. Saad, "Probióticos e prebióticos: o estado da arte," Revista Brasileira de Ciências Farmacêuticas, vol. 42, no. 1, pp. 1-16, 2006.

[46] B. C. Silva, L. R. C. Jung, S. H. C. Sandes et al., "In vitro assessment of functional properties of lactic acid bacteria isolated from faecal microbiota of healthy dogs for potential use as probiotics," Beneficial Microbes, vol. 4, no. 3, pp. 267-275, 2013.

[47] Z. V. Marshall-Jones, M.-L. A. Baillon, J. M. Croft, and R. F. Butterwick, "Effects ofLactobacillus acidophilusDSM13241 as a probiotic in healthy adult cats," American Journal of Veterinary Research, vol. 67, no. 6, pp. 1005-1012, 2006.

[48] S. N. Bybee, A. V. Scorza, and M. R. Lappin, "Effect of the probiotic Enterococcus faecium SF68 on presence of diarrhea in cats and dogs housed in an animal shelter," Journal of Veterinary Internal Medicine, vol. 25, no. 4, pp. 856-860, 2011.

[49] J. F. Garcia-Mazcorro, D. J. Lanerie, S. E. Dowd et al., "Effect of a multi-species synbiotic formulation on fecal bacterial microbiota of healthy cats and dogs as evaluated by pyrosequencing," FEMS Microbiology Ecology, vol. 78, no. 3, pp. 542-554, 2011.

[50] C. Gómez-Gallego, J. Junnila, S. Männikkö et al., “A caninespecific probiotic product in treating acute or intermittent diarrhea in dogs: a double-blind placebo-controlled efficacy study," Veterinary Microbiology, vol. 197, pp. 122-128, 2016.

[51] K. Kanakupt, B. M. Vester-Boler, B. R. Dunsford, and G. C. Fahey Jr., "Effects of short-chain fructooligosaccharides and galactooligosaccharides, individually and in combination, on nutrient digestibility, fecal fermentative metabolite concentrations, and large bowel microbial ecology of healthy adults cats," Journal of Animal Science, vol. 89, pp. 376-1384, 2011.

[52] M. K. Tripathi and S. K. Giri, "Probiotic functional foods: survival of probiotics during processing and storage," Journal of Functional Foods, vol. 9, pp. 225-241, 2014. 